\title{
Between Area-Based Initiatives and Community- Development Programmes. The Example of the Soziale Stadt Programme
}

\author{
Michat Nowosielski \\ Institute for Western Affairs, Poznań, Poland \\ e-mail: nowosielski@iz.poznan.pl
}

\begin{abstract}
Policymakers employ different programmes focused on tackling urban exclusion. Normally, such programmes can be divided into two separate groups: area-based initiatives and community-development programmes. However, there are also projects that try to combine those two modes of action. One example of such a combination is the Soziale Stadt programme, which has been carried out in German cities since the end of the 1990s. The aim of this article is to present the basic assumptions of the programme and to evaluate its outcomes - especially in the context of the joint application of the area-based and community-development approaches.
\end{abstract}

Key words: urban affairs, urban exclusion, activation, area-based initiatives, communitydevelopment, Soziale Stadt.

\section{Introduction}

Social differences are an immanent feature of every developed society. This is even more visible when we take under consideration social relations in the metaphor of contemporary society - the city. Since their beginnings, cities have been the places where social differences and inequalities have expressed themselves most strikingly. Poverty and wealth, hopelessness and power, social disrespect and esteem - all are congregated in a relatively small space adjoining each other. But what at first was only a part of urban colour has become, since the beginning of modern urbanization, a serious social problem. Such contrasts became too vivid, and brought with them too many serious consequences, as well as exasperating decent citizens, public opinion, and city governments. This is why urban exclusion has become one of the most researched subjects in the area of both urban studies and of exclusion studies (Madanipour, Cars and Allen, 2000.; Musterd and Ostendorf, 1998.; White, 1995.; Healy, 1997.; Andersen and van Kempen, 2001.). This is also a reason why this phenomenon is perceived by both urban researchers and practitioners as a serious problem, affecting not only quality of life, but also the very social order of contemporary cities. In fact, it is often perceived as a serious threat to society as a whole. Urban exclusion hinders the equal and sustainable development of society. 
Governments at different levels (from local municipal governments to supranational ones, such as the European Commission) are trying to develop specific programmes designed to tackle this social problem.

Tools to combat the social exclusion of the inhabitants of certain districts and neighbourhoods can, however, differ in their accepted modes of action. One can distinguish between two such modes: area-based initiatives (or policies), and communitydevelopment programmes. Area-based initiatives ${ }^{1}$ (ABIs) are focused on tackling local manifestations of social exclusion by reducing its causes-mostly of an economic, infrastructural, and ecological nature. ${ }^{2}$ Community-development programmes ${ }^{3}$ are less focused on making both the neighbourhoods and their residents more competitive, and more concentrated on the issue of participation in the life of the community. They pay attention to the collective, shared aspects of social problems that affect people's lives, and try to help members of communities to band together (Blackman, 1995.; Hautekeur, 2005.).

There are, however, programmes that attempt to combine both of those approaches. One example of such a method is the Socially Integrated City programme (Soziale Stadt), introduced in Germany at the end of the 1990s. ${ }^{4}$ The basic principle of the programme is to combine the traditional approach to revitalization with the idea of social activization. An intended consequence of the project has been the integration into society of residents from so-called districts with special developmental needs (Stadtteilen mit besonderem Erneuerungsbedarf), first by reviving the social bonds within the districts, and then the bonds between them and the rest of society. Multilevel actions (at the federal, state, city, district, and neighbourhood level) have been employed by the programme to improve the economic situation of the residents, their quality of life, their social engagement and participation, and the social bonds among them, as well as the infrastructure and the economy of the districts.

The aim of this article is to describe and evaluate the Soziale Stadt programme as an example of an initiative combining the area-based approach with the communitydevelopment tactic. It is intended to show whether this combination may be successful, and what might be the factors that determine the success and failure of such

\footnotetext{
$\mathbf{1}$ For a critique of such approaches, see Andersson and Musterd (2005.).

2 When they concentrate on the revitalization of space and the environment, they are called place-based ABIs. When their measures are focused on occupational activation of the socially excluded, they are referred to as people-based ABIs (Carpenter, 2006.:2147).

3 For general reflections on community development, see Bhattacharyya (2004.)

4 Where not otherwise indicated, information on the Socially Integrated City Programme is from the Soziale Stadt web page, http://www.sozialestadt.de/.
} 
projects. Looking at the experiences of other programmes tackling urban exclusion, ${ }^{5}$ these factors (excluding simple economic measures such as provision of financial resources) are the complexity of the programme, the engagement of the residents and other interest groups, and the programme's linkage with different policy levels.

The implementation of a project as complex as Soziale Stadt entails several important choices. The institutions responsible for designing the outlines of the programme had to face important questions such as what should be its focal issues? Which areas (districts) should be chosen for action? What fields of action, measures, and tools should be used during the implementation of the programme? The answers given to the first question are described in the first part of this paper. In the second part, the fields of actions and the specific measures implemented to fulfil the programme's goals will be presented. The last part of the paper discusses the outcomes of the project, and attempts to evaluate the consequences of the joint application of the area-based and community-development approach.

\section{Soziale Stadt: The choice of areas}

As Soziale Stadt is an atypical area-based initiative combined with the communitydevelopment approach, it is clear that is has to have specifically defined areas in which the programme's actions are implemented. Such an approach seems to be unique in Germany. As Rolf-Peter Löhr observes, "in Germany social measures targeting people rarely spotlight specific areas, but are classified according to certain groups of addressees and are always limited to individual cases. Attaching a district orientation to the Socially Integrative City programme, i.e. giving it a sociospatial approach, makes it an innovation in attacking social problems. It constitutes a revolution in youth services, welfare, health and labour policies" (Löhr, 2003.).

In the case of programmes designed at the level of the state, it is especially important to prepare a defined set of rules for selecting a specific district for the programme. This permits not only the effective selection of areas, but also makes better execution of the goal possible during the implementation of the programme. An outline of such rules is given by ARGEBAU (the German Building Ministers' Conference, Planning Panel of the Housing Committee) in its Guidelines for Implementation of the Joint Socially Integrative City Initiative: "Determining the limits of the district is the task of borough and town councils. Before they can do that they need a detailed picture of the envisioned improvements in the entire municipality. They must analyse all major aspects of life. Assisted areas must prove that their deficits place them distinctly below average" (Becker, 2003.).

5 "Contrats de Ville" within the French Urban Regeneration Programme, "Social Impulse Fund" in Flanders, and the Neighbourhood Renewal Unit in the United Kingdom. The latter has implemented a number of programmes: the New Deal for Communities, Neighbourhood Management, and Neighbourhood Wardens. 
In other words, the main criterion for inclusion in the Soziale Stadt programme is the presence of a special developmental need: the chosen district is supposed to be in such a bad condition that intervention is urgent and indispensable. Looking at the specifics of this special lack of development, it is worth noticing that the two main indicators are a high unemployment rate and an extreme dependence of the residents on welfare. In the chosen districts, the mean unemployment rate was 15.9 per cent, while the mean proportion of welfare clients was 14.8 per cent (Becker, 2003.). Other criteria included:

- urban shrinkage: drops in population, resulting in high vacant property rates (especially in the districts of the former East Germany).

- lack of social integration resulting in social conflicts. Shortages in integration are mainly caused by relatively high proportions of immigrants.

- lack of positive outlook among residents, including feelings of hopelessness and a lack of prospects of a better life.

- a negative image of the district among its residents and external audiences (including residents of other districts, municipal authorities, potential employers, and investors) (Becker, 2003.).

In 1999, the first selection procedure resulted in the acceptance of 161 districts in 24 towns and cities. Since 2000, the number has grown to 249 districts in 184 towns and cities. ${ }^{6}$ The selected districts are greatly differentiated, varying in a few important features:

- area: the average area of the disadvantaged districts selected for the programme is 126 hectares, varying from 1061 hectares in the case of Hagen-Vorhalle in North Rhine-Westphalia, to 1 hectare in the case of Rostock-Schmarl and SchwabachSchwalbenweg.

- location: about 20 per cent of the selected districts are located in the new eastern Länder, while the rest were West German Länder. Apart from this, 52 per cent of the selected districts were located in large towns with more than 100,000 inhabitants, and about half of these 52 per cent belonged to cities with populations exceeding 500,000 . At the same time, around 30 per cent of the districts were located in small towns with less than 50,000 residents.

- type of neighbourhood: there are two main types of neighbourhood that constitute districts with special development needs. The first are neighbourhoods of old buildings, dating from the beginning of industrialization, which are characterized by high population densities and relatively small areas. This kind of neighbourhood characterizes about 20 per cent of the selected districts. The second common kind of building is the "new" prefabricated estates typical of the 1960s, 1970s, and 1980s, called Plattenbausiedlungen in the former East Germany and Großtafelsiedlungen in the former West Germany. Although they are quite distinct, their common feature is their relatively large area. This kind of neighbourhood was typical of 55 per cent of the selected districts. The rest of the districts consisted of mixed neighbourhoods (Becker et al., 2002.).

6 In eight of these cases, the districts are part of both Soziale Stadt and the EC Initiative URBAN II programmes. 


\section{Fields of action}

Another important task was to choose fields of action, as well as the measures and tools to be used during implementation of the programme. In complex initiatives dealing with multifaceted urban exclusion, there is a wide range of problems to deal with: poverty, lack of integration, health problems, social deviancy, unemployment, disturbed ethnic relations, and many others. In the design of the Soziale Stadt programme, the most significant emphasis was placed on community cohesion, participation and activation, district culture, education, health promotion, the image of the districts, and the economy of the districts (Böhme et al., 2003.).

\section{Community cohesion}

Disintegration in district and neighbourhood life is one of the most serious problems caused by urban exclusion. The lack of social bonds between residents may lead to further negative consequences, among the most important of which are growing social conflicts between different social groups (e.g. ethnic or age groups). Usually, districts with special development needs are inhabited by greatly differentiated groups. Tension and a lack of social bonds are especially visible between ethnic groups-between native Germans and immigrants, or between different immigrant groups. Unfamiliarity, distrust, the feeling of being threatened, the strangeness, and the inability to communicate (often because of linguistic problems) are serious barriers to developing lively communities.

At the same time, the need to build effective social networks and robust communities is essential for the further development of districts. Such networks ought to be an important social actor in the improvement of the district and neighbourhood situation. For this reason, enhancement of community cohesion is one of the most important goals set by the Soziale Stadt programme. The specific measures implemented in order to develop communities were divided into two basic groups:

- intensifying social contact between neighbours: organizing meetings and encounters between residents of the districts. The basic form of such meetings has included various kinds of gatherings, such as festivals, fiestas, concerts, shows, etc. ${ }^{7}$ Apart from that, there have also been encounters organized on a regular basis (residents' meetings, different forms of counselling, discussion groups, and so on). ${ }^{8}$ A very important tool used to create a lively public sphere and to intensify contact and communication between residents is the use of meeting points where social relations can grow (e.g. district centres cafés, basketball courts, etc.) 9 This measure has,

${ }^{7}$ An example is the Stadtteilfest Miteinander organized in Rosenheim, Lessingstraße/Pfaffenhofener Straße.

8 See, for example, the Treffpunkt Mosaik Intercultural Workshops in Bremen-OsterholzTenever (Interkulturelle Werkstatt - Treffpunkt Mosaik, http://www.iw-tenever.de/).

9 An example of such a meeting place is the Stuhmer Straße Community House in BremenGröpelingen (Franke and Meyer, 2002.), or the Tenants Centre (Mieterzentrum) in LeinefeldeSüdstadt (Buhtz et. al., 2002. ). A district café project (Café BAFF) has been implemented in Darmstadt, Eberstadt-Süd. 
in some cases, been strengthened by language-teaching initiatives aimed at immigrants, which are intended to enable them to enter into or co-create social networks with German speaking residents. ${ }^{10}$ In other cases, the media have provided a public sphere in which neighbours can freely communicate and network. ${ }^{11}$

- conflict management: prevention, bridging, and resolving social conflicts between neighbours. ${ }^{12}$ Mediators, conflict solvers, and arbitrators are not external, but from among the residents of the deprived districts. It is typically not the police, the courts, or the social workers who try to find solutions to serious disagreements between neighbours; it is rather the residents themselves who need to find proper solutions. In some cases, the mediators have received special training to effectively manage social conflict, while in other cases the people undergoing arbitration have been taught to be themselves arbitrators. Schools have also spread knowledge on how conflicts may be avoided or solved peacefully.

\section{Participation and activation}

The lack of participation in the life of the district (taking decisions, engaging in common work, and so on), as well as the low level of social activity, are both important barriers which hinder the development of the districts. In fact, without the active participation of the residents, any other actions taken to improve their lives are pointless. Therefore, improving the participation and activation of the inhabitants is one of the most important aims of the whole programme (Franke, 2002.).

- Activation: this is understood by the authors of the programme to include any technique intended to improve communication between residents, which is crucial for further cooperation on district development (Franke, 2003.). Activation is also a way to stimulate residents to engage in common work and to participate in the affairs of their neighbourhood. The Soziale Stadt programme has used two sets of activation techniques - direct and indirect - that are intended to help the redevelopment of social engagement (Franke, 2003.). Some of the direct techniques that have been used include activation surveys (Böhme and Franke, 2002.).

- Social help; counselling; formal and informal meetings, and discussions among the residents; ${ }^{13}$ streetwork; creation and development of social networks; organization

10 See for example, projects such as Sprachförderung, Angebote zum Erlernen der deutschen Sprache, carried out in Piusviertel in Ingolstadt, or the Sprachförderprogramm Ahlen Süd/ Ost, Sprache - der Schlüssel zur interkulturellen Förderung, organized in Süd-Ost in Ahlen.

11 As in the case of the Netzwerk Nachbarschaft online community (http://www.netzwerknachbarschaft.de).

12 In Mülheim, Kalk und Vingst-Höhenberg in Köln, a Bureau for Conflict Resolution has been established under the name of Mülheimer Dialog. Another example is the conflict management and mediation provided by the Planerladen Association in Dortmund, Nordstadt (Planerladen Verein zur Förderung demokratischer Stadtplanung und stadtteilbezogener Gemeinwesenarbeit, http://www.planerladen.de/96.html).

13 Such discussions with residents and opinion leaders from the district have been organized in Ludwigshafen-Westend, among other places (Schröder and Werth, 2002.) 
of parties, picnics, parades, and other events; ${ }^{14}$ and mediation and conflict resolution. Indirect techniques have also been employed: publishing district newspapers, posters, leaflets, and websites; preparation of press releases for local media; and creation of logos and slogans for both the whole programme and its parts.

- Participation: this has a more precise aim and a more formal shape. It includes ways of involving residents in decision-making processes (Franke, 2003.). Through organizing district conferences, citizen forums, workshops, task groups, and participation-oriented projects, the residents become involved in discussions about the future of their neighbourhoods, and also in taking specific actions about it. ${ }^{15}$

\section{District culture}

Culture seemed to have a double meaning for the authors of the Soziale Stadt programme (Meyer and Schuleri-Hartje, 2002.). First, it was important as one of the vital elements of neighbourhood life. As stated earlier, districts with special development needs are usually socially and ethnically differentiated. This results in glaring cultural contrasts. But what in the case of social relations may be a source of constraints and conflicts, for cultural life is a chance to generate a unique mosaic of different cultural codes and creations, which can become a source of common identity for the residents of the district (Böhme et al., 2003.). Secondly, a colourful, differentiated, and creative culture not only expresses the identities of the different social groups, but can also be used as a tool for the development of the other focal issues of the programme. Culture and cultural events are often used as a measure of the creation of social contacts and bonds, an element of activation strategies, or as a part of actions taken to improve the negative image of a district.

Among the interesting examples of specific actions, one can point to the District Museum of Kottbusser Tor ${ }^{16}$ the Sachsendorf-Madlow Socio-Cultural Centre in Cottbus, ${ }^{17}$ and the Consol Theater in Gelsenkirchen-Bismarck/Schalke-Nord. ${ }^{18}$

${ }^{14}$ Such as the International Christmas Market and Bürgerplatz Party in Gelsenkirchen - Bismarck/Schalke-Nord (Austermann, Ruiz and Sauter, 2002.), or the Wir in Wabrenheide Stadteilfest in Hanover - Vahrenheide-Ost, (Geiling, Schwarzer, Heinzelmann and Bartnick, 2002.)

15 Example of such forums are the urban renewal meetings organized on a regular basis in Flensburg-Neustadt, (Frinken and Rake, 2002.), or the Bismarck/Schalke-Nord working party (Austermann et al., 2002.).

16 An initiative of the Society for the Study and Presentation of Kreuzberg History, which consisted of preparing the exhibition and initiating discussions about the history of the neighbourhood (Beer and Musch, 2002.)

$\mathbf{1 7}$ This centre has diverse functions aimed at improving social cohesion, social activity, and the development of district culture (Jahnke, Knorr-Siedow and Trostorff, 2002. ).

18 This youth theatre opened in a post-industrial building (Austermann et al., 2002.). 


\section{Education}

One of the biggest challenges to face programmes tackling social exclusion is to reverse the downward spiral of exclusion. This means that it is necessary to focus not only on the present problems of the district and its citizens, but also on the community's outlook - undoubtedly the most vital aspect of which is the preparation of the youth to participate in the labour market. Education plays an essential role in this process. At the same time, schools in districts with special development needs have a reputation of being a device that simply reproduces social structure, rather than improving the pupils' future lives. There are a few significant problems which lead to a deterioration in the functions of education in disadvantaged neighbourhoods. First, there are scarcities of resources (including of money, equipment, and welltrained staff). Second, there are social pathologies which strongly affect large numbers of pupils (parental neglect, alcoholism, drug additions, aggressive behaviour, etc.). And third, the specific character of a district with special development needs and its residents makes the process of education more difficult (on account of the linguistic problems of pupils and their parents, fluctuating attendance levels caused by frequently moving families, and so on). Not all of those problems have become subjects of actions of the Soziale Stadt programme. Its focus has been put on coping with linguistic problems and social disintegration, and adjusting the teaching process to the needs of the labour market (Böhme et al., 2003.).

- Linguistic problems: those of the pupils that have problems with effective communication in German have often received additional language support to help them in language acquisition. In some cases, the school also provides German lessons for parents ${ }^{19}$.

- Social disintegration: schools have been trying not only to implement new forms of teaching tailored to the specific social problems of pupils, as well as additional activities (e.g. sport and cultural activities), but have also been seeking ways to join in the life of the neighbourhood. They have set up cooperation with other social and institutional actors who have been involved in carrying out important tasks in the Soziale Stadt programme..$^{20}$

- Adjusting the teaching process to labour market needs: this involves making teaching more realistic and focused on acquiring practical skills needed in the labour market. Apart from this, schools have been cooperating with local business and

19 An example of such a project is Mama und Papa lernen Deutsch, a part of a broader scheme described earlier-Sprachförderung, Angebote zum Erlernen der deutschen Sprache, carried out in Piusviertel in Ingolstadt.

20 For example, in Ludwigshafen-Westend in 2000, a children's conference was organized. One of the results of the discussion was the rebuilding of the playgrond in the Erich Kästner Primary School (Schröder and Werth, 2002.). 
employment institutions, in order to create networks that will help pupils find work after finishing school. ${ }^{21}$

\section{Health promotion}

Problems with health are usually connected with social exclusion. The excluded have less access to health care, their lifestyle and quality of life are often unhealthy, and they are rarely receivers of health promotion. At the same time, living in disadvantaged districts brings more health risks as compared to other urban areas, in particular in terms of noise and air pollution, high risk of accidents, and a lack of recreation spaces.

One of the most essential tasks that the authors of Soziale Stadt have taken is in the improvement of preventive health action. This means more emphasis on health promotion among different groups of deprived district inhabitants. So far, "preventive medical services and health promotion primarily target the middle class, and therefore rarely benefit the more disadvantaged sections of the population" (Böhme et al., 2003.). Children and youth have been defined as the most important target group of such actions (Löhr, Geene and Halkow, 2003.), which have usually been applied to the promotion of healthy eating habits, ${ }^{22}$ as well as to exercise and sport. ${ }^{23}$ Apart from that, youth have become the targets of actions aiming to prevent addictions and violence. The second target group of health prevention actions is women. ${ }^{24}$

\section{District image}

Deprived districts have very poor social images - both externally and internally. External audiences perceive them as dangerous, dodgy places, where crime and social pathologies bloom. This image is even strengthened by the media, where the names

$\mathbf{2 1}$ Examples of education projects implemented under the Soziale Stadt programme include the Homework Circle project (Schularbeitenzirkel - SCHATZ) in Berlin-Kreuzberg-Kottbusser Tor, which involved specially hired teachers helping 7th-grade pupils with their homework (Beer and Musch, 2002.), and RAZ-Mobil (Ran an die Zukunft-Tackling the Future) in Bremen-Gröpelingen, which has provided young people leaving school with special assistance in finding jobs, as well as extra training and professional counselling (Franke and Meyer, 2002.).

22 The Lernen geht durch den Magen (Learning Through the Stomach) project, implemented in Wuppertal-Ostersbaum, consisted of organizing a Kinderkantine offering healthy food for groups of pupils of secondary schools.

$\mathbf{2 3}$ As in the case of the Jugend mit Zukunft ins nächste Jahrtausend project in DuisburgMarxloh.

24 An example of such project is the Frauengesundheitstreff, organized in Bremen-OsterholzTenever. 
of these districts appear only in the negative contexts of crime and conflict. The internal audience - the residents themselves - find in some cases their neighbourhoods hostile, and perceive themselves as castaways in a sea of brutality, crime, and social problems. This image, and its perception by the inhabitants, is a serious threat to the development of a district, especially in terms of social activity and participation. It can lead to discouragement and a feeling that it is senseless to make any effort towards improving life in the district. In this sense, the actions taken to improve district images have had to go in two directions (Böhme et al., 2003.):

- improvement of the internal image: this involves actions undertaken in order to improve the image of the district in the eyes of its inhabitants. They have consisted of emphasizing the positive sides of district life, such as cultural and social diversity, the multitude of differentiated events organized in the neighbourhood, an appreciation of the district's history, etc. These measures have, however, always been implemented in association with other actions, such as those aimed at improving social cohesion, district culture, or activation. The tools used to development of a positive internal image include events (concerts, festivals, etc. ${ }^{25}$ district media (newspapers, ${ }^{26}$ web-sites,${ }^{27}$ etc.), leaflets, and brochures giving information about interesting places and events. ${ }^{28}$

- improvement of the external image: here the emphasis is placed on creating a positive image in the wider media: local, regional, and national. These actions consist of presenting information about the positive side of life in the district, and above all the positive changes that have affected these neighbourhoods. ${ }^{29}$

\section{Local economy}

One of the problems that hinders the growth of deprived districts is the poorly developed local economy. Although in today's globalized world, locality does not seem to be essential for economic growth, the authors of the Soziale Stadt programme have put special emphasis on rebuilding the economies of the districts (Cramer, Behrens, 2001.). This focus comes from the conviction that "local economy approaches are intended to tap the resources and address the needs of residents and companies where they live and operate and to support economic development, using spatially limited precision instruments" (Cramer, Behrens, 2001.). In other words, supporting local economies can be an effective tool for tackling urban exclusion, especially by increasing the number of jobs in a district.

\footnotetext{
25

25 E.g. QuartiersRap Kotti in Berlin-Kreuzberg - Kottbusser Tor,

26

Like Quartierkurier in Berlin-Kreuzberg - Kottbusser Tor, Neustadt News in Flensburg Neustadt, Lurup im Blick in Hamburg-Altona - Lurup,

$\mathbf{2 7}$ Such as the website of Bremen - Gröpelingen: www.groepelingen.de, or of Leipziger Osten http://www.leipziger-osten.de.

28

Like the Socially Integrative City. East Leipzig: 'Let's get started! leaflets, as well as the posters and postcards prepared by the Leipzig municipal authorities (Böhme and Franke, 2002.)

29

For example, in Singen-Langenrain, press releases have been prepared, and some journalists were invited to write about the district (Geiss, Heckenroth and Krings-Heckemeier, 2002.).
} 
The peculiarity of the local-economy approach entails few specific measures (Cramer and Behrens, 2001.):

- strengthening the existing, and encouraging the establishment of new, indigenous businesses: special support is guaranteed for people engaged in local business (sponsorship, encouragement, training, networking, etc.) ${ }^{30}$

- promotion of employment: as a strong local economy needs an active and qualified labour force, actions towards labour activation of inactive residents, as well as training aimed at qualification of potential workers, has been undertaken. ${ }^{31}$ In some cases, in order to overcome linguistic problems of the unemployed, German language courses have been started.

- development of social economy: not-for-profit enterprises managed by third sector organizations have been encouraged to support the Soziale Stadt programme (e.g. district and domestic service agencies, neighbourhood clubhouses, school cafeterias, cafes, etc.). ${ }^{32}$

\section{Environment}

The revitalization of districts would seem to be the easiest task, requiring only financial resources. However districts with special development needs are characteristic in that often they are not only underinvested in, but also have damaged environments (houses and flats, streets and pavements, public spaces, etc.). Revitalization of such deprived environments takes not only money, but also time. Apart from that, cooperation between different actors is necessary in order to achieve satisfactory results. These actors are the municipal authorities, the owners of the buildings, the members of local initiatives and organizations, and the individual residents. Implementation of such revitalization plans has also became part of other measures, such as activation and participation, promotion of employment, and the development of district culture.

Revitalization projects have been implemented at different levels. In some cases, a single street has been renovated, ${ }^{33}$ in others, an entire estate. ${ }^{34}$ Green areas have also undergone revitalization..$^{35}$

30 A Hamburg association, Beschäftigung + Bildung, operating in the districts of St. Pauli and Ottensen, provides help (counselling, networking, etc.) for small enterprises; see Beschäftigung + Bildung, (http://www.bb-ev.de).

31 An example of promoting employment is the Job Club Mobil, a counselling and advisory office in Hamburg-Altona-Lurup (Breckner, Herrmann, 2002.).

32 The Women's Organization of Großbreitenbach in Thuringia has created numerous jobs by providing housekeeping, childcare, travel, and many other services; see Frauengruppe Großbreitenbach, (http://www.frauengruppe-grossbreitenbach.de).

33 Such as the redesign of Neustadt Straße in Flensburg (Frinken, Rake, 2002.).

34 See, for example, the redevelopment of the Klingethal Estate in Hanover - VahrenheideOst (Geiling et al., 2002.).

35 E.g. the Südstadt Green Offensive, aimed at extending green spaces in the district (Cramer and Strauss, 2002.). 


\section{Evaluation}

Tackling multidimensional urban exclusion requires the application of complex measures. The Soziale Stadt programme combines a typical area-based approach (focused on the economic, infrastructural, and ecological causes of urban exclusion) with a community-development tactic (focused on social cohesion and the participation of the urban excluded). It takes on several problems, such as revitalization of infrastructure, participation and activation, education, health promotion, district culture, and economy. However, the evaluation of the programme's outcomes shows that not all of its goal have been obtained to equal levels.

The revitalization of the infrastructure and the outlook of the district was the easiest part of the project. Investment in the "tissue" of districts with special development needs brought about an increase in the quality of life for the inhabitants. The overall environment-streets and buildings, as well as public places such as recreation grounds, playgrounds, and so on-has been improved. This, together with the actions taken to improve the districts' culture (or at least its material aspects) and image, has turned out to be the most successful part of the programme. The reason for this may be that the investments required mainly financial resources.

Other changes were much harder to achieve. The example of community cohesion and participation and the activation of residents is most striking, and it reveals the characteristic limits of the programme. Although there has been a distinct improvement in social activity among the residents, this was achieved by cooperation with those who were objectively the least affected by social exclusion. Those who most needed help failed to identify themselves with the aims and actions of the programme. Thus one might have observed activities of the programme that turned out to be attempts to socially include those who had already been included, and to integrate those who had already been integrated. This is especially visible in the case of the integration of immigrants, which in most cases failed. As the interim appraisal of the Soziale Stadt programme states, "There are many ideas and also a considerable number of projects. But they do not live up to the tasks, apart from a few exceptions" (Aehnelt, Häußermann, Jaedicke, Kahl and Toepel, 2004.:13). It should be mentioned that the engagement of residents in the development of the districts' cultures seems to be one of the most effective measures to improve their participation in district matters.

Further problems appear when one takes into consideration other fields of action, such as education. Although different measures have been taken to improve this sphere, it seems that in many cases not all of the goals have been reached. Although many of the schools' infrastructures and educational services have been developed, the role of schools in the life of the neighbourhood has not significantly broadened. Cooperation with other actors involved in the programme proved to be more problematic than expected, and almost no sustained links or networks were established. This has resulted in a limitation of the role that schools play in the entire programme.

Health promotion is a typical casualty of the programme's complexity. Although it concerns one of the most important and fundamental aspects of life quality, it seems 
to disappear somewhere in the hierarchy of problems. Apart from that, the health of the residents of districts with special developmental needs is affected by many other problems that are subject to actions of the Soziale Stadt programme, such as poverty or environment. In many cases, therefore, particular actions have had a bearing on health, but rather unintentional than planned.

The greatest problem, however, seems to be the development of the local economy. This goal has not been reached so far, and will probably not be reached in the future. In this context, one may assert that the assumption that the district economy would be strengthened proved to be utopic. Even if local businesses had improved with the support of the programme, the chances of improving the whole local economy, and especially the local labour market, were poor. Therefore the expectations regarding this sphere of the programme failed.

The Soziale Stadt programme has been innovative and pioneering in its scope and breadth, both in its measures and its aims. It has also been one of the most comprehensive projects of urban development and integration, as it focused on many interconnected spheres. The theoretical assumption that complex and multilevel actions can be more effective was ambitious, and gave to Soziale Stadt the impetus that many other programmes lacked. The compound character of the programme expresses itself in multilevel governance and in the differentiated package of specific measures used during the execution of the project, as well as in the diverse set of districts chosen for the programme. It also properly identified the most important spheres of urban exclusion that needed intervention and revitalisation. Moreover, the initiating of cooperation between different actors (authorities at different levels, NGOs, interests groups, residents of districts with special developmental needs) should be evaluated positively, as it helped to offset some of the consequences of the programme's complexity.

Yet in practice it turned out to be difficult to combine the assumptions and objectives of all the programmes. Many of the goals of Soziale Stadt have not lived up to their expectations. The evaluation of programme goals shows that only some of them have been fulfilled to date, and in many cases these successes have been only partial. The reasons for this may indeed be manifold, but it is worth mentioning that the complexity of the programme is not only an advantage; it may also be a shortcoming, if not an outright threat. It has turned out that some of the objectives simply escaped the programme's notice (for example, health promotion) while others have proven to be too ambitious and difficult to fulfil (the local economy goals). Second, the selected tools were not always adequate-for example, the actions on activation and participation were insufficient as they simply did not attract most of the excluded. Third, it seems that goals that go beyond simple revitalization (such as integration and activation) take time and cannot be achieved in a relatively short time.

This last argument is also important in formulating an overall assessment of the programme. The Soziale Stadt programme is ongoing, which means that, owing to the systematic evaluation of the programme's outcomes, measures can be taken to improve its effectiveness. Besides, the time factor should also bring more efficiency 
to actions targeted at tackling those dimensions of urban exclusion that have social and psychological, rather than material and economic, backgrounds. This gives us a hope of finding better solutions to the problems of urban exclusion, including within the framework of the Soziale Stadt programme.

\section{Literature}

1. Aehnelt R.; Häußermann, H.; Jaedicke, W.; Kahl, M.; Toepel, K. (2004). Interim Appraisal of the Federal-Länder-Programme "Districts with special development needs - the Social City" ("Soziale Stadt"). Berlin: Institut für Stadtforschung und Strukturpolitik.

2. Andersen, H. T. and van Kempen, R. (Ed.). (2001). Governing European Cities: Social Fragmentation, Social Exclusion and Urban Governance. Aldershot, UK: Ashgate.

3. Andersson, R. and Musterd, S. (2005). Area-based policies: a critical appraisal. Tijdschrift voor Economische en Sociale Geografie, 96 (4): 377-389.

4. Austermann, K.; Ruiz, M. and Sauter, M. (2002). Berichte aus den Modellgebieten Gelsenkirchen - Bismarck/Schalke-Nord, in: Die Soziale Stadt - Eine erste Bilanz des Bund-Länder-Programms Stadtteile mit besonderem Entwicklungsbedarf - die soziale Stadt. Berlin: Deutschen Institut für Urbanistik.

5. Becker, H. (2003). Special Development Needs-Socially Integrative City Programme Districts, in: Socially Integrative City Strategies. Berlin: German Institute of Urban Affairs.

6. Becker, H.; Franke, T.; Löhr, R. P. and Rösner, V. (2002). Drei Jahre Programm Soziale Stadt - eine ermutigende Zwischenbilanz, in: Die Soziale Stadt - Eine erste Bilanz des Bund-Länder-Programms Stadtteile mit besonderem Entwicklungsbedarf - die soziale Stadt. Berlin: Deutschen Institut für Urbanistik.

7. Beer, I. and Musch, R. (2002). Berichte aus den Modellgebieten: Berlin-Kreuzberg - Kottbusser Tor, in: Die Soziale Stadt - Eine erste Bilanz des Bund-LänderProgramms Stadtteile mit besonderem Entwicklungsbedarf - die soziale Stadt. Berlin: Deutschen Institut für Urbanistik.

8. Bhattacharyya, J. (2004). Theorizing Community Development. Journal of the Community Development Society, 34 (2): 5-33.

9. Blackman, T. (1995). Urban Policy in Practice. New York: Routledge.

10. Böhme C. and Schuleri-Hartje, U. K. (2003). Health Promotion - Key Integrated Urban District Development Topic. Read on 23 January 2008. (http://www.sozialestadt.de/en/veroeffentlichungen/newsletter/gesundheitsfoerderung.phtml).

11. Böhme, C.; Becker, H.; Meyer, U.; Schuleri-Hartje, U. K.; Strauss, W. C. (2003). Handlungsfelder integrierter Stadtteilentwicklung, in: Soziale Stadt-Strategien für die Soziale Stadt, Erfabrungen und Perspektiven - Umsetzung des BundLänder-Programms ,Stadtteile mit besonderem Entwicklungsbedarf- die soziale Stadt". Berlin: Deutschen Institut für Urbanistik.

12. Böhme, C. and Franke, T. (2002). Berichte aus den Modellgebieten Leipzig - East Leipzig, in: Die Soziale Stadt - Eine erste Bilanz des Bund-Länder-Programms Stadtteile mit besonderem Entwicklungsbedarf - die soziale Stadt. Berlin: Deutschen Institut für Urbanistik. 
13. Breckner, I. and Herrmann, H. (2002). Berichte aus den Modellgebieten Hamburg-Altona - Lurup, in: Die Soziale Stadt - Eine erste Bilanz des Bund-LänderProgramms Stadtteile mit besonderem Entwicklungsbedarf - die soziale Stadt. Berlin: Deutschen Institut für Urbanistik.

14. Buhtz, M.; Lindner, M.; Gerth, H.; Weeber, R. (2002). Berichte aus den Modellgebieten Leinefelde - Südstadt, in: Die Soziale Stadt - Eine erste Bilanz des Bund-Länder-Programms Stadtteile mit besonderem Entwicklungsbedarf - die soziale Stadt. Berlin: Deutschen Institut für Urbanistik.

15. Carpenter, J. (2006). Addressing Europe's Urban Challenges: Lessons from the EU URBAN Community Initiative. Urban Studies, 43 (12): 2145-2162.

16. Cramer, C. and Behrens, J. (2001). Lokale Ökonomie - eine zentrale Strategie für die Soziale Stadt. Soziale Stadt Info, 5: 2-7.

17. Cramer, C. and Strauss, W. C. (2002). Berichte aus den Modellgebieten Nuremberg - Galgenhof-Steinbühl, in: Die Soziale Stadt - Eine erste Bilanz des BundLänder-Programms Stadtteile mit besonderem Entwicklungsbedarf - die soziale Stadt. Berlin: Deutschen Institut für Urbanistik.

18. Franke, T. (2002). Aktivierung und Beteiligung im Rahmen des Programms "Soziale Stadt". Soziale Stadt Info, 7: 2-6.

19. Franke, T. (2003). Aktivierung und Beteiligung, in: Soziale Stadt-Strategien für die Soziale Stadt, Erfahrungen und Perspektiven - Umsetzung des Bund-LänderProgramms „Stadtteile mit besonderem Entwicklungsbedarf- die soziale Stadt”. Berlin: Deutschen Institut für Urbanistik.

20. Franke, T. and Meyer, U. (2002). Berichte aus den Modellgebieten: BremenGröpelingen, in: Die Soziale Stadt - Eine erste Bilanz des Bund-Länder-Programms Stadtteile mit besonderem Entwicklungsbedarf - die soziale Stadt. Berlin: Deutschen Institut für Urbanistik.

21. Frinken, M. and Rake, H. (2002). Berichte aus den Modellgebieten Flensburg Neustadt, in: Die Soziale Stadt-Eine erste Bilanz des Bund-Länder-Programms Stadtteile mit besonderem Entwicklungsbedarf - die soziale Stadt. Berlin: Deutschen Institut für Urbanistik.

22. Geiling, H.; Schwarzer, T.; Heinzelmann, C.; Bartnick, E. (2002). Berichte aus den Modellgebieten Hanover - Vahrenheide-Ost, in: Die Soziale Stadt - Eine erste Bilanz des Bund-Länder-Programms Stadtteile mit besonderem Entwicklungsbedarf - die soziale Stadt. Berlin: Deutschen Institut für Urbanistik.

23. Geiss, S.; Heckenroth, M. and Krings-Heckemeier, M. T. (2002). Berichte aus den Modellgebieten Singen - Langenrain, in: Die Soziale Stadt - Eine erste Bilanz des Bund-Länder-Programms Stadtteile mit besonderem Entwicklungsbedarf - die soziale Stadt. Berlin: Deutschen Institut für Urbanistik.

24. Hautekeur, G. (2005). Community development in Europe. Community Development Journal, 40 (4): 385-398.

25. Healy, P. (1997). Social exclusion, neighbourhood life and governance capacity, in: Housing in Europe. Hørsholm, Denmark: Statens Byggeforskningsinstitut.

26. Jahnke, K.; Knorr-Siedow, T. and Trostorff, B. (2002). Berichte aus den Modellgebieten Cottbus - Sachsendorf-Madlow, in: Die Soziale Stadt - Eine erste Bilanz des Bund-Länder-Programms Stadtteile mit besonderem Entwicklungsbedarf - die soziale Stadt. Berlin: Deutschen Institut für Urbanistik. 
27. Löhr, R. P. (2003). Socially Integrative City-the cooperation and confrontation between urban research and urban policy in Germany. Paper prepared for the EURA-Eurocities-MRI Conference, "European urban development, research and policy - the future of European cohesion policy", Budapest, 28-30 August 2003.

28. Löhr, R. P.; Geene, R. and Halkow, A. (Ed.). (2003): Die soziale Stadt-Gesundbeitsförderung im Stadtteil. Berlin: b_books.

29. Madanipour, A.; Cars, G. and Allen, J. (Ed.). (2000). Social Exclusion in European Cities. Processes, Experiences and Responses. Second impression. London: The Stationery Office.

30. Meyer, U. and Schuleri-Hartje, U. (2002). Kultur im Stadtteil. Soziale Stadt Info, 10: $2-7$.

31. Musterd, S. and Ostendorf W. (Ed.). (1998). Urban Segregation and the Welfare State. Inequality and Exclusion in Western Cities. London: Routledge.

32. Schröder, D. and Werth, M. (2002). Berichte aus den Modellgebieten Ludwigshafen - Westend, in: Die Soziale Stadt - Eine erste Bilanz des Bund-LänderProgramms Stadtteile mit besonderem Entwicklungsbedarf - die Soziale Stadt. Berlin: Deutschen Institut für Urbanistik.

33. Soziale Stadt NRW. Die Kinderkantine - Lernen geht durch den Magen. Read on 15 June 2007. (http://www.sozialestadt.nrw.de/praxis/p28.html).

34. White, P. (1995). Ideologies, Social Exclusion and Spatial Segregation in Paris, in: Urban Segregation and the Welfare State. Inequality and Exclusion in Western Cities. London: Routledge. 
Michat Nowosielski

Institute for Western Affairs, Poznań, Poland

e-mail: nowosielski@iz.poznan.pl

\section{Između inicijative koncentrirane na teritorij (određeno područje) i programa razvoja cjelokupne zajednice: primjer Soziale Stadt programa}

\section{Sažetak}

Gradske vlasti provode razne programe usmjerene na borbu protiv socijalne isključenosti na području grada. Takvi se programi, obično, mogu podijeliti u dvije osnovne vrste: inicijative koncentrirane na teritorij (određeno područje) i programi razvoja zajednica. Međutim, provođeni su i projekti koji su kombinacija tih dviju vrsta djelovanja. Primjer takve kombinacije jeste program Soziale Stadt koji se provodi u njemačkim gradovima od 1990-ih godina. Ovaj članak ima za cilj predstaviti osnovne pretpostavke programa i ocjenu njegovih rezultata, a naročito u kontekstu primjene oba pristupa u borbi protiv socijalne isključenosti: inicijativa koncentriranih na teritorij (određeno područje) i programa razvoja zajednica.

Ključne riječi: urbani problemi, socijalna isključenost, aktivacija, inicijative koncentrirane na teritorij (određeno područje), razvoj zajednice, Soziale Stadt. 